Г.В. Пєвцов ${ }^{1}$, С.В. Залкін ${ }^{1}$, П. Пацек ${ }^{2}$, О.В. Ревін ${ }^{1}$, С.О. Сідченко ${ }^{1}$, К.І. Хударковський ${ }^{1}$

${ }^{1}$ Харківський національний університет Повітряних Сил ім. І. Кожедуба, Харків

${ }^{2}$ Академія військового мистеитвва, Варшава

\title{
МЕТОДИЧНИЙ ПІДХІД ДО ВИЗНАЧЕННЯ ПІДРОЗДІЛІВ ДЛЯ ЗДІЙСНЕННЯ ПРОТИДІЇ НЕГАТИВНОМУ ІНФОРМАЦІЙНОМУ (ПСИХОЛОГІЧНОМУ) ВПЛИВУ ПРОТИВНИКА НА ОСНОВІ ОЦІНЮВАННЯ ЇХ СПРОМОЖНОСТЕЙ
}

У статті представлений методичний підхід до визначення підрозділів для здійснення протидії негативному інформаційному (психологічному) впливу противника на основі оцінювання їх спроможностей за методикою DOTMLPFI. Проаналізовано причини недостатньої ефективності протидії негативному інформаційному (психологічному) впливу на особовий склад на початку Антитерористичної операції, визначені основні завдання з протидії негативному інформаційному (психологічному) впливу. Запропоновані схема процедур планування протидії негативним інформаційним (психологічним) впливам та варіант типової групи спроможностей “Протидія негативним інформаційним (психологічним) впливам”. Наведені результати оцінювання спроможності “Аналіз та прогнозування інформаційного (психологічного) впливу противника”, щзо розраховані авторами.

Ключові слова: інформаційний (психологічний) вплив, оцінювання спроможності підрозділу, протидія, спроможність, об'єкт інформаційного впливу.

\section{Вступ}

Постановка проблеми. 3 початку XXI століття провідні держави світу все більш активно використовують інформаційний простір для вирішення різноманітних геополітичних, економічних, військовополітичних та інших завдань.

Загальні тенденції розвитку інформаційного простору як середовища для проведення інформаційних та психологічних операцій (IПсО) (впливів) свідчать про зростання рівня загроз в інформаційному просторі [1].

Аналіз сучасного стану інформаційного протиборства свідчить про те, що війська та населення постійно знаходяться під негативним інформаційним (психологічним) впливом (ІПВ), який здійснюється як в мирний час, так і в загрозливий період та в ході конфлікту [1-8].

Під негативним інформаційним (психологічним) впливом розуміється дія інформації, або дія за допомогою інформації з використанням спеціальних методів, засобів і технологій, що загрожує інформаційній безпеці особи, суспільства, держави, становить небезпеку індивідуальній або суспільній свідомості, завдає шкоди фізичному чи психологічному здоров'ю особи або спонукає її до певних дій (бездіяльності) [9].

Основним об'єктом впливу з боку противника є психіка особового складу сил сектору безпеки та оборони і цивільного населення держави, а розвиток інформаційних технологій суттєво загострюють і підсилюють проблему психологічної небезпеки.
Результати аналізу ведення бойових дій на початку Антитерористичної операції (АТО) на сході України свідчать, що головним фактором, який негативно впливав на особовий склад, була масова загибель та поранення військовослужбовців військової частини, що спричиняло зневіру у власних силах, рівні підготовки командирів, з'являвся фактор невизначеної небезпеки та страху за власне життя, перевищення оцінки рівня бойового вишколу незаконних збройних формувань. Особовий склад виказував незадоволення рівнем особистої підготовки, рівнем матеріально-технічного забезпечення, рівнем підготовки сержантського та офіцерського складу, наголошував на відсутності довіри до керівного складу військової частини та вищого керівництва. Найбільш негативно на морально-психологічний стан особового складу впливала відсутність ефективного керівництва у низовій ланці (відділення, взвод) управління.

Основними причинами недостатньої ефективності протидії негативному ІПВ на особовий склад на початку АТО можна вважати неготовність на той час керівного складу військових частин і підрозділів організовувати бойову діяльність в умовах негативного ІПВ та слабку систему захисту особового складу та населення від негативного ІПВ противника та відсутність дієвої ієрархічно побудованої структури планування та виконання заходів інформаційнопсихологічної протидії.

Тому, протидія негативному ІПВ є одним із основних завдань щодо забезпечення високого моральнопсихологічного стану особового складу збройних сил.

Аналіз останніх досліджень і публікацій. Небезпека негативного ІПВ полягає, перш за все, в 
тому, що він може призвести до зниження морального духу особового складу та боєготовності військових частин (підрозділів) i, як наслідок, невиконання поставлених бойових завдань.

Основні завдання 3 протидії негативним ІПВ [10-11] полягають в:

- аналізі та прогнозуванні ІПВ противника в районах постійної дислокації частин і підрозділів 3С України та у районах виконання бойових завдань;

- запобіганні негативному ІПВ противника на особовий склад та населення в районах виконання бойових завдань частинами і підрозділами ЗС України;

- зриві інформаційних (психологічних) впливів противника на свої війська та населення в районах дислокації частин і підрозділів;

- ліквідації наслідків негативного ІПВ противника.

3 метою якісного планування заходів протидії негативному ІПВ необхідно розробити методичний підхід до визначення та оцінювання необхідних спроможностей підрозділів для виконання завдань 3 протидії ІПВ противника [12, с. 16].

Під спроможністю розуміється здатність структурної одиниці (елементу) Збройних Сил (сил оборони) або сукупності сил і засобів виконувати певні завдання (забезпечувати реалізацію визначених військових цілей) за певних умов обстановки, ресурсного забезпечення та відповідно до встановлених стандартів [12, с. 5].

Тож, оцінювання спроможностей військових частин (підрозділів) для виконання завдань 3 протидії негативному IПВ противника $є$ актуальним науковим завданням.

Мета статті - розробка методичного підходу до визначення підрозділів для здійснення протидії негативному ІПВ противника на основі оцінювання їх спроможностей за методикою DOTMLPFI.

\section{Виклад основного матеріалу}

Визначення підрозділу для протидії негативному ІПВ розпочинається з оцінки обстановки.

Під оцінкою обстановки щодо протидії негативному ІПВ розуміється визначення сукупності всіх об'єктивних умов щодо своєчасного виявлення негативних ІПВ та вибір найбільш доцільних заходів щодо зриву та ліквідації наслідків негативного ІПВ противника на особовий склад військових частин (підрозділів) та населення.

Основна мета вивчення обстановки полягає у виявленні ознак і початку здійснення негативного ІПВ противника, встановленні джерел та каналів впливу, визначенні об'єктів впливу та рівня інформаційно-психологічних загроз.

Оцінка обстановки щодо протидії негативному ІПВ здійснюється у декілька етапів:

- в ході підготовчого етапу визначаються: а) мета і завдання оцінювання обстановки, суб'єкти оцінювання, їх можливості, ресурси, засоби, а також окремі питання, які потребують особливої уваги під час оцінювання;

б) напрями проведення аналізу та оцінки обстановки, посадові особи, відповідальні за оцінювання;

в) уточнюються часові показники (терміни) оцінювання обстановки, форма та порядок звітності;

- в ході збору бази даних (інформації) визначаються:

а) джерела негативної інформації;

б) канали негативної інформації;

- в ході систематизації, аналізу та узагальнення даних:

а) здійснюється систематизація за операційними складовими обстановки;

б) проводиться поділ та порівняння чинників обстановки за операційними змінними і складовими $з$ подальшим вивченням їх властивостей;

в) визначається рівень інформаційнопсихологічних загроз;

- під час прогнозу формулюються:

а) можливі наслідки негативного ІПВ;

б) зміни обстановки внаслідок співпраці та взаємодії з різними суб'єктами ii формування в районах дислокації та виконання військовими частинами (підрозділами) завдань за призначенням;

в) визначаються можливі профілактичні заходи щодо запобігання негативних наслідків ІПВ на особовий склад.

Висновки 3 оцінки обстановки є основою для визначення цілей та завдань 3 протидії негативному IПВ. За результатами формування цілей та завдань 3 протидії негативному ІПВ визначається підрозділ (підрозділи), який (які) буде (будуть) реалізовувати відповідні заходи та на який (які) буде покладена відповідальність за результати протидії негативному ІІВ.

Визначення такого підрозділу (підрозділів) - це окремий захід, який потребує системного підходу до оцінювання його (ix) спроможностей та за необхідності виділення додаткових ресурсів.

Схема процедур планування протидії негативним ІПВ на основі оцінювання спроможностей підрозділів представлена на рис. 1 .

Необхідність набуття спроможностей з протидії негативному ІПВ потребує удосконалення процедур планування та підготовки заходів з протидії негативному ІПВ, тому пропонується методичний підхід до визначення підрозділу (підрозділів) для здійснення протидії негативному інформаційному (психологічному) впливу противника на основі оцінювання його (ix) спроможностей за методикою DOTMLPFI. 

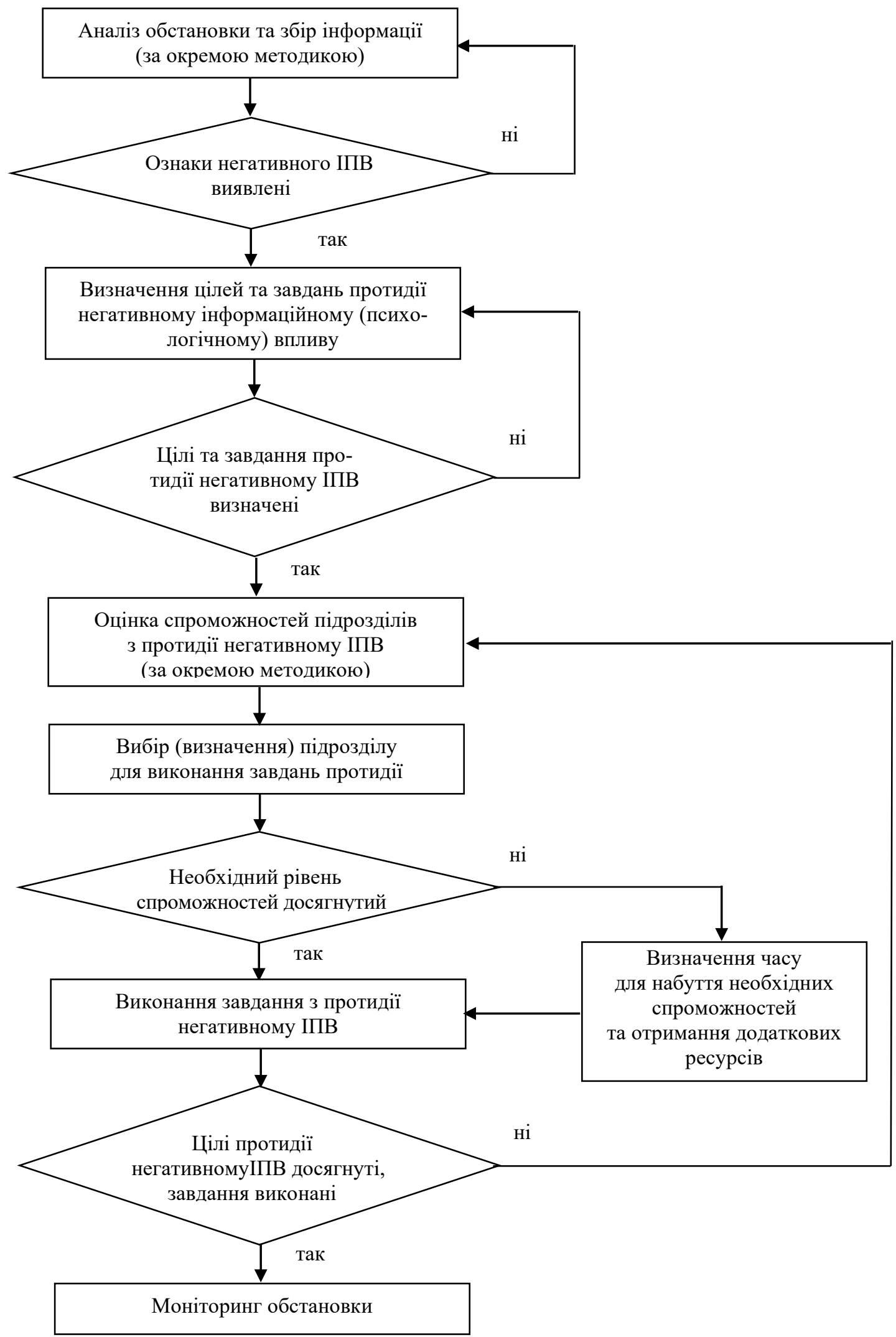

Рис. 1. Схема процедур планування протидії негативним IПВ на основі оцінювання спроможностей підрозділів

Джерело: розроблено авторами.

Методика DOTMLPFI використовується в країнах-членах НАТО для оцінювання спроможностей підрозділів і прийнята в Україні для оборонного планування в Міністерстві оборони України та
Збройних Силах України [12-13].

Авторами запропонований варіант типової групи спроможностей "Протидія негативним IПВ”, представлений у табл. 1. 
Спроможності підрозділів з протидії негативному інформаційному

(психологічному) впливу (варіант)

\begin{tabular}{|c|c|c|}
\hline $\begin{array}{l}\text { Типова група } \\
\text { спроможностей }\end{array}$ & Код і назва спроможності & Базова вимога спроможності \\
\hline \multirow[t]{4}{*}{$\begin{array}{l}\text { Протидія } \\
\text { негативним } \\
\text { ІПВ }\end{array}$} & $\begin{array}{l}\text { 1. Аналіз та прогнозування інформа- } \\
\text { ційного (психологічного) } \\
\text { противника }\end{array}$ & $\begin{array}{l}\text { 1.01. Здатність аналізувати та оцінювати обста- } \\
\text { новку в районах дислокації та ведення бойових } \\
\text { дій військ (сил) та рівень ії впливу на війська } \\
\text { (сили) та населення }\end{array}$ \\
\hline & 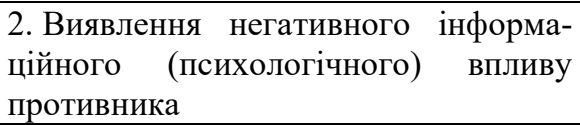 & $\begin{array}{l}\text { 2.01. Здатність виявляти джерела негативного } \\
\text { ІПВ }\end{array}$ \\
\hline & \multirow[t]{2}{*}{$\begin{array}{l}\text { 3. Зрив та ліквідація наслідків інфор- } \\
\text { маційних (психологічних) впливів } \\
\text { противника }\end{array}$} & $\begin{array}{l}\text { 3.01. Здатність швидко виявляти засоби негатив- } \\
\text { ного ІПВ, їх негайно придушувати (знищувати) } \\
\text { або нейтралізувати }\end{array}$ \\
\hline & & $\begin{array}{l}\text { 3.02. Здатність організовувати ліквідацію нас- } \\
\text { лідків інформаційних (психологічних) впливів } \\
\text { противника }\end{array}$ \\
\hline
\end{tabular}

Джерело: розроблено авторами.

Наведені спроможності оцінюються за базовими, основними та додатковими вимогами відповідно до методики DOTMLPFI (Doctrine, Organization, Training, Material, Leadership, Personnel, Facilities, Interoperability), що визначає базові компоненти (складові) спроможності.

Методика DOTMLPFI передбачає оцінювання за наступними критеріями (показниками):

- D - керівні документи (чинні доктринальні документи);

- О - організація (організаційна структура i склад наявних підрозділів);

- Т - підготовка (рівень підготовки особового складу до виконання завдань за призначенням);

- М - ресурсне забезпечення (забезпеченість необхідним зразками матеріально-технічних засобів для виконання завдань);

- L - якість управління та освіта (наявність належного рівня професійної підготовки особового складу, що забезпечує функціонування і розвиток);

- P - персонал (наявність кваліфікованого та вмотивованого особового складу);

- F - інфраструктура (наявність відповідної інфраструктури та здатність забезпечити виконання завдань за призначенням);

- I - взаємосумісність (рівні доктринальної, оперативної та технічної сумісності з відповідними підрозділами сил НАТО та країн-партнерів).

Оцінювання спроможностей здійснюється групою експертів. Експертна оцінка полягає у виконанні низки обов'язкових елементів, що визначають етапи її проведення:

a) складання плану та програми експертизи:

б) формування групи експертів, визначення іiі кількісного та якісного складу; в) проведення експертної оцінки;

г) групування та зведення матеріалів експертизи;

д) розрахунок статистичних показників;

е) визначення ступеня збігу думок експертів;

ж) узагальнення результатів експертизи.

Оцінювання рівня спроможності може здійснюватись як за фактом наявності спроможності, тобто 0 або 1, так і оцінюватись чисельними значеннями в інтервалі від 0 до 1.

Формат представлення результатів оцінювання спроможностей підрозділу 1 за методикою DOTMLPFI на прикладі спроможності 1 наведений у табл. 2. Результати оцінювання спроможності “Аналіз та прогнозування інформаційного (психологічного) впливу противника” (сектор 1 рис. 2) розраховані авторами. Аналогічно оцінюються спроможності інших підрозділів.

Приклад візуалізації результатів оцінювання спроможностей підрозділу 1 з протидії негативному IПВ за методикою DOTMLPFI представлений на рис. 2 .

На рис. 2 відображені три сектори результатів оцінювання відповідних спроможностей (табл. 1, 2) та критичні, наявні і необхідні спроможності [12, с. 5] підрозділу 1.

Необхідні спроможності - ті, що повинні бути в розпорядженні відповідного командира (начальника) у визначений час та місці, для виконання завдань у певних умовах середовища 3 необхідним результатом (ефектом). 
Формат представлення результатів оцінювання спроможностей за методикою DOTMLPFI (варіант)

\begin{tabular}{|c|c|c|c|c|c|}
\hline $\begin{array}{l}\text { № } \\
\text { 3/ח }\end{array}$ & Підрозділ & $\begin{array}{c}\text { Код і назва } \\
\text { спроможності }\end{array}$ & $\begin{array}{c}\text { Базові, основні та додаткові } \\
\text { вимоги спроможності }\end{array}$ & $\begin{array}{c}\text { Критерій } \\
\text { (показник) } \\
\text { оцінювання } \\
\text { спроможності }\end{array}$ & $\begin{array}{c}\text { Результат } \\
\text { оцінювання }\end{array}$ \\
\hline 1. & Підрозділ 1 & $\begin{array}{lr}\text { 1. Аналіз та } & \text { про- } \\
\text { гнозування } & \text { iнфор- } \\
\text { маційного } & \text { (психо- } \\
\text { логічного) } & \text { впливу } \\
\text { противника } & \end{array}$ & 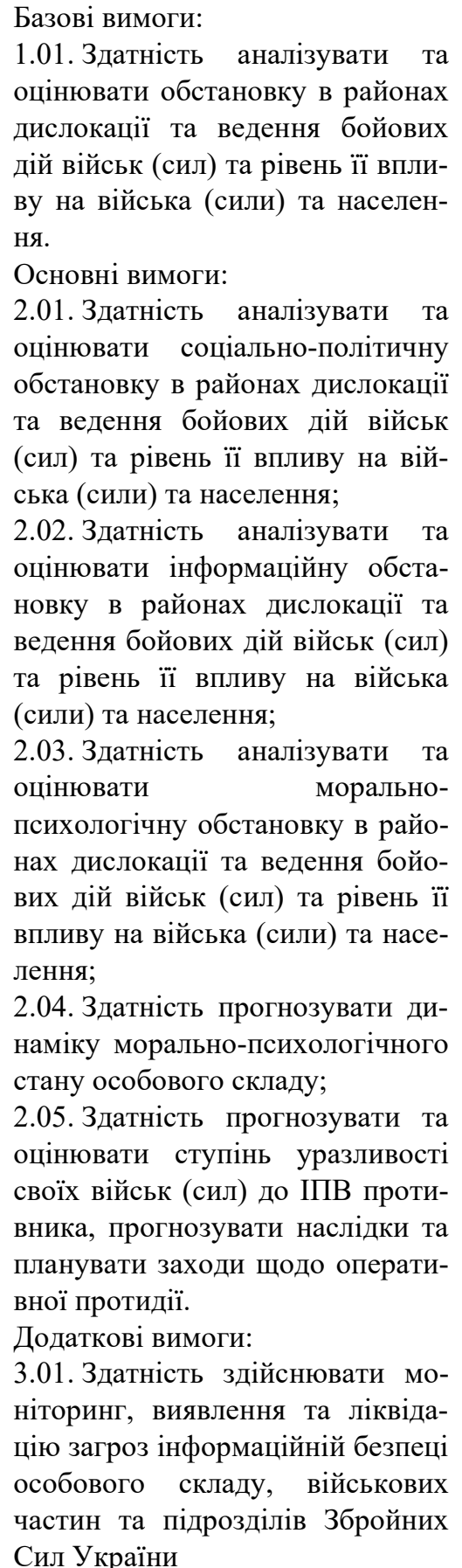 & $\begin{array}{l}\mathrm{D} \\
\mathrm{O} \\
\mathrm{T} \\
\mathrm{M} \\
\mathrm{L} \\
\mathrm{P} \\
\mathrm{F} \\
\mathrm{I}\end{array}$ & $\begin{array}{c}0,66 \\
0,8 \\
0,54 \\
0,4 \\
0,56 \\
0,54 \\
0,4 \\
0,44\end{array}$ \\
\hline
\end{tabular}

Джерело: розроблено авторами.

Наявні спроможності - ті, що є у розпорядженні відповідного командира (начальника) для виконання завдань, але можуть бути недостатніми для досягнення необхідного результату (ефекту).

Критичні спроможності - ті, що є абсолютно важливими для досягнення необхідного результату (ефекту) відповідною структурою та потребують створення (розвитку) та утримання у пріоритетному порядку [11, с. 5].

Рівень критичних, наявних та необхідних спроможностей визначається, виходячи із завдань підрозділу у мирний та воєнний час. 


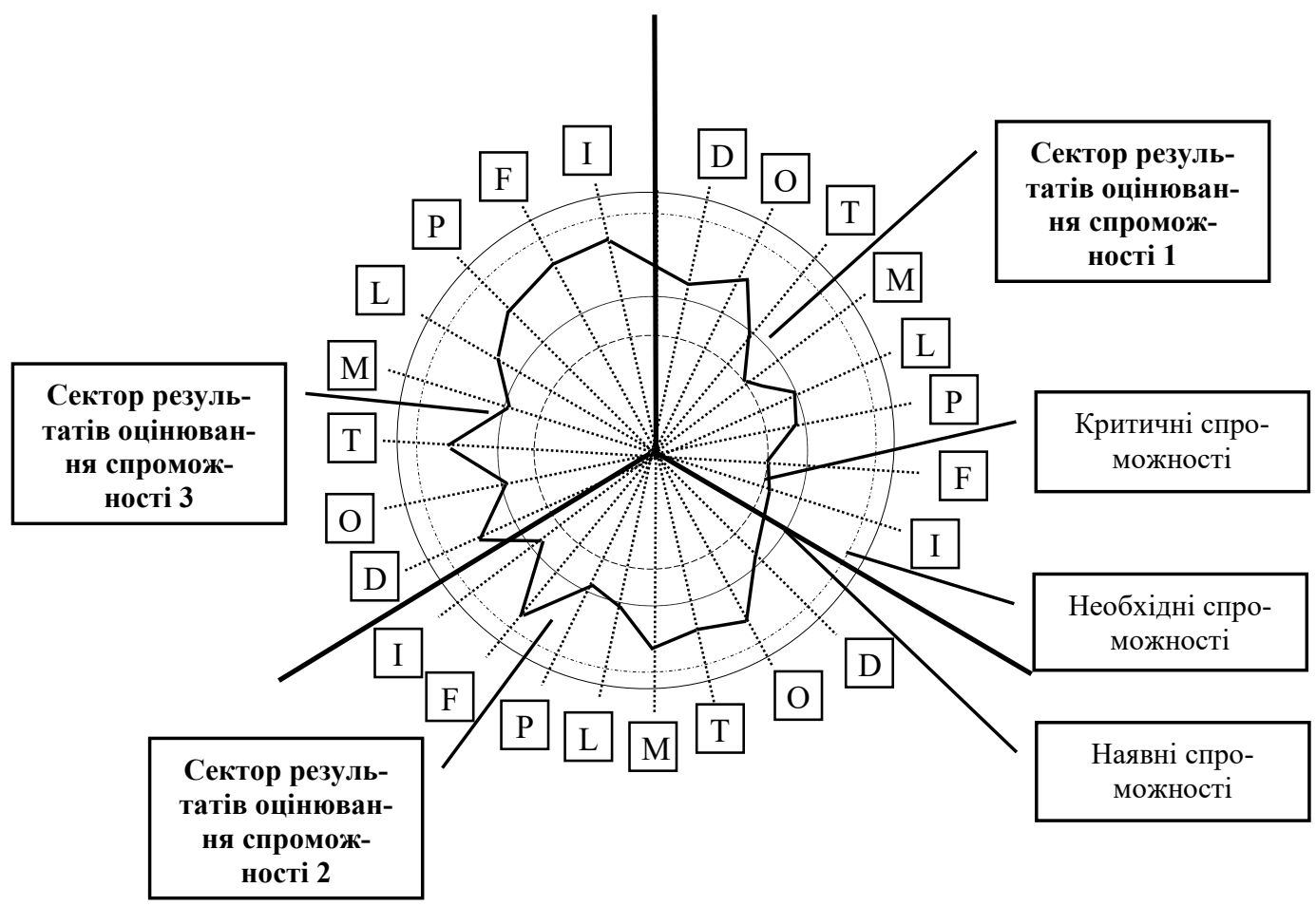

Рис. 2. Візуалізація результатів оцінювання спроможностей підрозділу 1 з протидії негативному IПВ за методикою DOTMLPFI (приклад) Джерело: розроблено авторами.

Підрозділ для здійснення протидії ІПВ обирається за досягненням необхідного рівню спроможностей або, якщо жодний з підрозділів не досяг такого рівня, то на основі визначення мінімального часу, необхідного для набуття відповідного рівня за умов отримання додаткових ресурсів.

\section{Висновки}

Розроблений методичний підхід до визначення підрозділів для здійснення протидії негативному ІПВ противника на основі оцінювання їх спроможностей. В основу даного підходу покладена методика DOTMLPFI, що використовується в країнах-членах НАТО для оцінювання спроможностей підрозділів.

Перелік спроможностей $з$ протидії негативному IПВ не є вичерпним і може змінюватись. Оцінювання спроможностей здійснюється групою експертів незалежно один від одного із подальшим узагаль- ненням результатів оцінювання статистичними методами. Наведені спроможності оцінюються за базовими, основними та додатковими вимогами відповідно до методики DOTMLPFI. При цьому, оцінювання рівня спроможності може здійснюватись як за фактом наявності спроможності, так і чисельними значеннями в інтервалі від 0 до 1.

Підрозділ для здійснення протидії ІПВ обирається за досягненням необхідного рівню спроможностей або, якщо жодний з підрозділів не досяг такого рівня, то на основі визначення мінімального часу, необхідного для набуття відповідного рівня за умов отримання додаткових ресурсів.

Системний підхід до протидії негативним ІПВ дає можливість державі та їі Збройним Силам ефективно протистояти інформаційним загрозам та реалізовувати свої стратегічні інтереси в сучасному інформаційному просторі.

\section{Список літератури}

1. Інформаційно-психологічні операції: планування, протидія, технології : монографія / Пєвцов Г. В. , Залкін С. В., Сідченко С. О., Хударковський К. І. Харків : ДІСА ПЛЮС, 2020. 252 с.

2. Деркаченко Я. Інформаційно-психологічні операції як сучасний інструмент геополітики. Глобальна організація союзницького лідерства. 2016. URL: http:/goal-int.org/informacijno-psixologichni-operacii-yak-suchasnij-instrumentgeopolitiki/ (дата звернення: 26.05.2021).

3. Шевчук П. І. Інформаційно-психологічна війна Росії проти України: як їй протидіяти. Демократичне врядування. 2014. Вип. 13. URL : http://nbuv.gov.ua/UJRN/DeVr_2014_13_11 (дата звернення: 26.05.2021). 
4. Інформаційно-психологічна протидія в Національній гвардії України (психологічний аспект) : монографія / Воробйов І. В. та ін. Харків : Національна акад. НГУ, 2016. 265 с.

5. Мороз Ю., Твердохліб Ю. Інформаційно-психологічні операції в умовах гібридної війни. Вісник Львівського університету. Серія міжнародні відносини. 2016. Вип. 38. C. 97-105. http://nbuv.gov.ua/UJRN/VLNU_Mv_2016_38_12.

6. Хворост Х. Ю. Інформаційно-психологічний вплив у розрізі безпеки здоров’я. Наука $і$ освіта. 2016. № 2-3. C. 184-191. https://doi.org/10.24195/2414-4665-2016-2-3-33.

7. Чистоклетов Л. Г., Шишко В. Й. Інформаційно-психологічні впливи як невід'ємна складова парадигми інформаційної безпеки. Науковий вісник Львівського державного університету внутрішніх справ. 2012. № 2(1). С. 183-193. URL : http://nbuv.gov.ua/UJRN/Nvldu_2012_2(1)_24 (дата звернення: 28.05.2021).

8. Panasiuk A., Zubrytska H. Information Support of Russian Media for the Tourist Destination of Crimea. Sustainability. 2021. 13(6):3228. https://doi.org/10.3390/su13063228.

9. Військовий стандарт ВСТ 01.004.004-2014(01) Воєнна політика, безпека та стратегічне планування. Інформаційна безпека держави у воєнній сфері. Терміни та визначення. [Чинний від 2014-02-27]. Вид. офіц. Київ, 2014. 22 с. (Інформація та документація).

10. Пєвцов Г. В., Гордієнко А. М., Залкін С. В., Сідченко С. О., Хударковський К. І. Підхід до визначення раціонального складу окремих сил та засобів протидії негативному інформаційно-психологічному впливу противника на війська та населення. Наука і техніка Повітряних Сил. 2017. № 3(28). С. 5-13. https://doi.org/10.30748/nitps.2017.28.01.

11. Хударковський К. І., Залкін С. В., Пєвцов Г. В., Пацек П., Сідченко С.О. Механізм протидії негативному інформаційно-психологічному впливу на особовий склад Збройних Сил України. Наука і техніка Повітряних Сил Збройних Силах України. 2020. № 1(38). С. 72-78. https://doi.org/10.30748/nitps.2020.38.08.

12. Рекомендації з оборонного планування на основі спроможностей в Міністерстві оборони України та Збройних Силах України : затверджено Міністром оборони України 12.06.2017 р. Вид. офіц. Київ, 2017. 29 с.

13. Порядок проведення оборонного огляду Міністерством оборони : Постанова Кабінету Міністрів України від 31 жовтня 2018 р. № 941. URL : https://www.kmu.gov.ua/npas/pro-zatverdzhennya-poryadku-provedennya-oboronnogo-oglyaduministerstvom-oboroni (дата звернення: 26.05.2021).

Надійшла до редколегії 04.10.2021

Схвалена до друку 16.11.2021

\section{Відомості про авторів:}

\section{Псвцов Геннадій Володимирович}

доктор технічних наук професор

заступник начальника Харківського національного

університету Повітряних Сил ім. І. Кожедуба

3 наукової роботи,

Харків, Україна

https://orcid.org/0000-0002-0426-6768

\section{Залкін Сергій Володимирович}

кандидат військових наук старший науковий співробітник провідний науковий співробітник

Харківського національного університету

Повітряних Сил ім. І. Кожедуба,

Харків, Україна

https://orcid.org/0000-0002-0518-4414

\section{Пацек Петро}

доктор філософії

викладач Академії військового мистецтва,

Варшава, Польща

https://orcid.org/0000-0002-2182-2316

Ревін Олександр Володимирович

заступник начальника науково-організаційного відділу

Харківського національного університету

Повітряних Сил ім. І. Кожедуба,

Харків, Україна

https://orcid.org/0000-0001-8758-6419

\section{Сідченко Сергій Олександрович}

кандидат технічних наук старший науковий співробітник докторант Харківського національного

університету Повітряних Сил ім. І. Кожедуба,

Харків, Україна

https://orcid.org/0000-0002-1319-6263

\section{Information about the authors:}

\author{
Hennadii Pievtsov \\ Doctor of Engineering Science Professor \\ Deputy Head of Ivan Kozhedub \\ Kharkiv National Air Force University \\ in Science, \\ Kharkiv, Ukraine \\ https://orcid.org/0000-0002-0426-6768
}

\section{Sergii Zalkin}

$\mathrm{PhD}$ in Military Science Senior Researcher

Leading Researcher

of Ivan Kozhedub

Kharkiv National Air Force University,

Kharkiv, Ukraine

https://orcid.org/0000-0002-0518-4414

\section{Piotr Pacek}

Doctor of Philosophy

Lecturer of The War Studies University,

Warsaw, Poland

https://orcid.org/0000-0002-2182-2316

\author{
Alexander Revin \\ Deputy Head of the Scientific-Organizational Department \\ of Ivan Kozhedub Kharkiv National \\ Air Force University, \\ Kharkiv, Ukraine \\ https://orcid.org/0000-0001-8758-6419

\section{Sergii Sidchenko} \\ $\mathrm{PhD}$ in Engineering Senior Researcher \\ Doctoral Candidate \\ of Ivan Kozhedub Kharkiv National Air Force University, \\ Kharkiv, Ukraine \\ https://orcid.org/0000-0002-1319-6263
}


Хударковський Костянтин Ігорович

кандидат технічних наук доцент старший науковий співробітник старший науковий співробітник

Харківського національного університету

Повітряних Сил ім. І. Кожедуба,

Харків, Україна

https://orcid.org/0000-0002-9508-9014
Konstantin Khudarkovskij

$\mathrm{PhD}$ in Engineering Associate Professor

Senior Researcher

Senior Researcher

of Ivan Kozhedub Kharkiv National

Air Force University,

Kharkiv, Ukraine

https://orcid.org/0000-0002-9508-9014

\title{
МЕТОДИЧЕСКИЙ ПОДХОД К ОПРЕДЕЛЕНИЮ ПОДРАЗДЕЛЕНИЙ ДЛЯ ОСУЩЕСТВЛЕНИЯ ПРОТИВОДЕЙСТВИЯ НЕГАТИВНОМУ ИНФОРМАЦИОННОМУ (ПСИХОЛОГИЧЕСКОМУ) ВОЗДЕЙСТВИЮ ПРОТИВНИКА НА ОСНОВЕ ОЦЕНИВАНИЯ ИХ ВОЗМОЖНОСТЕЙ
}

\author{
Г.В. Певцов, С.В. Залкин, П. Пацек, А.В. Ревин, С.А. Сидченко, К.И. Хударковский
}

В статье представлен методический подход к определению подразделений для осушествления противодействия негативному информационному (психологическому) воздействию противника на основе оченки их возможностей по методике DOTMLPFI. Проанализированы причины недостаточной эффективности противодействия негативному информационному (психологическому) воздействию на личный состав в начале Антитеррористической операции, определены основные задачи по противодействию негативному информационному (психологическому) воздействию. Предложены схема прочедур планирования противодействия негативным информационным (психологическим) воздействиям и вариант типовой группы возможностей "Противодействие негативным информачионным (психологическим) воздействиям”. Приведены результаты оиенки возможности “Анализ и прогнозирование информационного (психологического) воздействия противника", рассчитанные авторами.

Ключевые слова: возможность, информационное (психологическое) воздействие, объект информационного воздействия, оценивание возможностей подразделений, противодействие.

\section{METHODICAL APPROACH TO THE DEFINITION OF SUBDIVISIONS TO COMBAT THE NEGATIVE INFORMATIONAL (PSYCHOLOGICAL) IMPACT OF THE ENEMY BASED ON THE ASSESSMENT OF THEIR CAPABILITIES}

H. Pievtsov, S. Zalkin, P. Pacek, O. Revin, S. Sidchenko, K. Khudarkovskij

The article presents a methodical approach to the definition of units for counteracting the negative informational (psychological) impact of the enemy based on the assessment of their capabilities by the method of DOTMLPFI. The DOTMLPFI methodology is used in NATO member countries to assess the capabilities of units and is adopted in Ukraine for defense planning in the Ministry of Defense of Ukraine and the Armed Forces of Ukraine. Defining units to counter the negative informational (psychological) impact of the enemy is an important measure that requires a systematic approach to assessing their capabilities and, if necessary, the allocation of additional resources.

The article analyzes the reasons for the lack of effectiveness in counteracting the negative informational (psychological) impact on personnel at the beginning of the Anti-Terrorist Operation and identifies the main tasks for combating negative informational (psychological) impact. The main measures taken during the assessment of the situation are presented. During the study of the situation, the signs of negative informational (psychological) influence and its beginning are revealed, the sources and channels of influence are established, the objects of influence and the level of threats are determined. Conclusions from the assessment of the situation are the basis for determining the goals and objectives of counteracting the negative informational (psychological) impact on personnel.

The scheme of procedures of planning of counteraction to negative informational (psychological) impacts and a variant of a typical group of abilities "Counteraction to negative informational (psychological) impacts" are offered. Capacities are assessed by basic, basic and additional requirements. Capacity assessment is carried out by a group of experts. The results of the ability assessment "Analysis and forecasting of informational (psychological) impact of the enemy" calculated by the authors.

Keywords: assessment of the capabilities of units, counteraction, informational (psychological) impact, object of informational impact, opportunity. 